\title{
SPECIAL NEEDS OF YOUNG WOMEN WITH BREAST CANCER IN LIMITED RESOURCE SETTINGS
}

\author{
Carmen Lizette Gálvez-Hernández ${ }^{1,2}$, María Cecilia González-Robledo ${ }^{3 *}$, \\ Regina BarRagán-CARrillo ${ }^{2,4}$ AND CYNTHIA VILLARREAL-Garza ${ }^{2,4,5}$
}

${ }^{1}$ Catedrática-CONACYT, Instituto Nacional de Cancerología, Mexico City, Mexico; ${ }^{2}$ Joven y Fuerte: Programa para la Atención e Investigación de Mujeres Jóvenes con Cáncer de Mama, Mexico City, Mexico; ${ }^{3}$ Centro de Investigación en Sistemas de Salud, Instituto Nacional de Salud Pública, Cuernavaca, Mor., Mexico; ${ }^{4}$ Centro de Cáncer de Mama, Hospital Zambrano Hellion, Tecnológico de Monterrey, Monterrey, NL, Mexico; ${ }^{5}$ Department of Investigation and Breast Tumors, Instituto Nacional de Cancerología, Mexico City, Mexico

\begin{abstract}
Background: Young women with breast cancer (YWBC) comprise a group of patients with unique biopsychosocial characteristics with a special perception of needs throughout their disease and survivorship. Contexts marked by restricted allocations and economic constraints might further aggravate the struggle of these patients living within limited resource settings and can demand added requirements for them and their families. Objective: To analytically explore the existing knowledge regarding the needs of YWBC in low- and middle- income countries (LMICs). Methods: We conducted a thorough literature review of scientific journal databases available in Spanish and English containing information on YWBC in LMICs. Results: We did not find any publications exclusively assessing this topic in resource-limited settings. We looked for data on the different types of YW need from studies in the region that assessed the needs of breast cancer (BC) patients in general and described in their findings the particularities of young patients. Young BC patients described within the literature present a variety of needs. Those reported most frequently as unmet were related to information needs and psychological counseling, practical and physical assistance, and social and spiritual support. Conclusions: Published literature on the subject - particularly in Latin America - is extremely scarce. This offers an area of opportunity for conducting further research in this topic that would help improve health professional training and establish health policies in favor of YWBC.
\end{abstract}

Key words: Needs assessment. Supportive care needs. Breast cancer. Young women. Low- and middle-income countries. Latin America.

\section{BACKGROUND}

Breast cancer $(B C)$ is the leading cause of cancer-related death and disability among women in low- and middle-income countries (LMICs) $)^{1,2}$, where the proportion of incident and fatal cases among women aged $\leq 45$ years is substantial: $20 \%$ versus $12 \%$ in high-income countries (HICs) for incidence and $14 \%$ versus $7 \%$ for mortality, respectively ${ }^{2}$. In Mexico, for example, $B C$ is the second-leading cause of death among women aged $30-54$ years ${ }^{3}$. Hence, understanding

\section{Corresponding author:}

*María Cecilia González-Robledo

Centro de Investigación en Sistemas de Salud Instituto Nacional de Salud Pública

Av. Universidad, 655

Santamaría Ahuacatitlán

C.P. 62100, Cuernavaca, Mor., México

E-mail: cecilia.gonzalez@insp.mx and assisting young women (YW) who are facing this disease in resource-limited contexts acquires great relevance.

YWBC is regarded as a special population with distinctive requirements based on at least three considerations: (1) Cancer presenting at a young age is often diagnosed at advanced stages, with a higher frequency of more aggressive subtypes; therefore, it has been associated with a poor prognosis ${ }^{2,4-7}$. (2) Young $\mathrm{BC}$ patients often receive aggressive and prolonged
Received for publication: 10-05-2017

Approved for publication: 16-06-2017

doi: 10.24875/RIC.17002285 
treatments that can be associated with important long-term morbidity ${ }^{8,9}$. (3) Finally, YWBC is subject to significant psychosocial vulnerability resulting from high levels of emotional distress and depression associated with oncological interventions ${ }^{2,6,10}$. The preceding factors pose complex issues for YWBC, particularly in regard to their family, social, and professional lives ${ }^{8,11}$, thereby substantially undermining their quality of life $2,10,12$.

\section{Context: Countries with limited resources}

Countries with limited health resources fall under the category of LMICs and are characterized by insufficient funds to cover the individual and public healthcare needs, which include limited access to medicine and health-related equipment, rudimentary infrastructure, and deficient or inadequately trained clinical personnel ${ }^{13}$. These conditions differentiate health outcomes from patients in $\mathrm{HICs}$ compared to those in LMICs. For instance, the rate of 5 -year BC survival in HICs ranges between $80 \%$ and $90 \%$, but falls to $40-60 \%$ in LMICs and even to a staggering $12 \%$ in parts of Africa ${ }^{13,14}$.

Furthermore, the epidemiology of BC differs greatly between regions. Compared with $\mathrm{BC}$ patients in $\mathrm{HICS}$, those in LMICs are diagnosed at younger ages ${ }^{7,13,15}$. For instance, a study in Kenya reported that the mean age of $\mathrm{BC}$ diagnosis was 44 years $^{16}$, in contrast to 61 years in the USA. In Latin America, one of every 5 cases is diagnosed in women aged $<45$ years, almost twice as many as in $\mathrm{HICs}^{15}$. The contrasting ages of onset among HICs and LMICs have been attributed to the younger age distribution of LMICs populations compared with developed countries. However, biological and genetic differences have also been adduced ${ }^{13}$.

In addition, BC in LMICs is usually detected at more advanced stages than in HICs, owing largely to protracted diagnosis and treatment ${ }^{17}$. This has been explained by various factors, including lack of awareness, limited access to diagnostic evaluations and treatment initiation, cultural attitudes among women such as fatalist outlooks (beliefs and/or taboos), stigma surrounding cancer, and gender discrimination ${ }^{17,18}$.

Other significant burdens that BC diagnosis confers young patients in poor countries are profound and long-lasting repercussions on the economy of the families and community, owing largely to the role of women as labor and sustenance providers, a situation which has increased appreciably in recent years ${ }^{17}$. This acquires particular relevance in the case of $\mathrm{YW}$, where the number of lost years of potential productivity is critical $^{2}$.

Given the paucity of research into the requirements of this young population group ${ }^{19,20}$, studies are greatly needed to characterize this vulnerable population, particularly those living in socioeconomic disadvantage marked by little access to health care. In this manuscript, we aim to analytically explore existing knowledge regarding the needs of YWBC in LMICs to provide a better understanding of their specific requirements and to guide the future targeted strategies for healthcare providers in limited resource settings.

\section{METHODS}

A systematic search was conducted in English and Spanish publications. YW was operationally defined as $\leq 40$ years old at the time of diagnosis. Limited resource settings included all the countries classified in low-income ( $G N I$ per capita $\$ 1,025$ or less), lower middle-income ( $\$ 1,026$ and $\$ 4,035)$, and upper middle-income (GNI per capita $\$ 4,036$ and $\$ 12,475$ ) economies according to the World Bank Group report. To assess the supportive care needs of young $B C$ patients in LMIC, the following key words were searched for in both English and Spanish: BC or breast neoplasm, young or younger, supportive care needs or supportive care or psychosocial care or need or unmet need or needs assessment, limited resource settings, low income economies, developing countries, emerging economies, poor countries, as well as with the particular names of countries belonging to the groups of the low-income economies, lower-middle income, and upper-middle income economies. Studies that have assessed unmet needs of women with $\mathrm{BC}$, including young patients, and have been conducted in limited resource settings were considered for review. To determine perceived needs, we used two conceptual frameworks of supportive care needs and quality of life, adapted for cancer survivors $^{21,22}$. Epidemiological studies carried out in HICs, and data from mixed cancer types were excluded.

Since there are no publications that exclusively assessed this topic among young BC population in LMICs, we pursued data on the different types of needs of $\mathrm{YW}$ from studies conducted in the region which assessed the needs of $B C$ patients in general 
and in their findings described the particularities of young patients. Fig. 1 shows a flowchart of the selection process for including manuscripts to be discussed in this review. Tables 1 and 2 provide further details on studies' findings.

\section{Supportive care needs of YWBC}

For the purpose of presentation in this manuscript, we classified supportive care needs into six main clusters according to the two conceptual frameworks of needs and quality of life adapted to cancer survivors: (1) Physical, (2) psychological, (3) information and health system, (4) social, (5) spiritual, and (6) practical needs. Furthermore, the different stages of survivorship were also taken into account: Acute or short-term (immediately after diagnosis), extended or medium-term (end of the initial cancer treatment), and permanent or long-term (when cancer treatment ends and patients must readapt to their daily lives) ${ }^{21,22}$.

\section{Physical needs}

It is well known that YWBC experience treatment-derived side effects, consisting mainly of induced ovarian failure, premature menopause, infertility, osteoporosis, and weight gain ${ }^{23}$. Regarding sexual activity, most studies report the presence of sexual dysfunction, impaired sexual desire, and low frequency of sexual activity ${ }^{24,25}$. As for cognitive function, the most frequently affected domains include speed of processing, attention, and memory, that is, a number of women have been found to experience difficulty in remembering things, reading the newspaper, and watching television $^{26-29}$. The rest of the treatment-related morbidity associated with systemic and local therapy is similar to that of the general BC patients, mainly including headaches, xerostomia, nausea, dysgeusia, alopecia, lymphedema, alterations in skin integrity (erythema and desquamation), and radiated area pain, among others ${ }^{25,30-32}$.

Figure 1. Flowchart of literature review process.
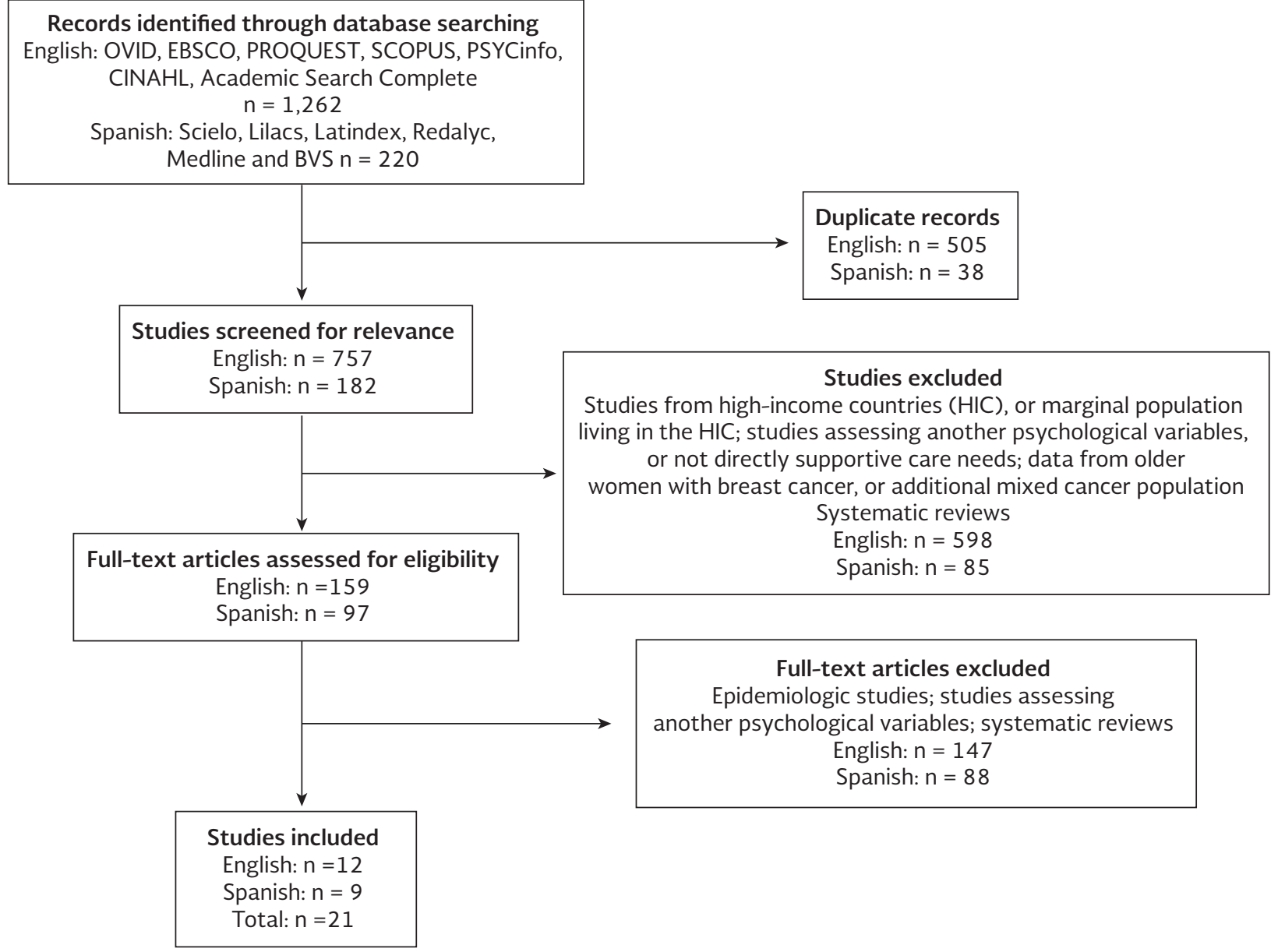
Table 1. Variables of interest, population, and design of studies addressing special needs of YWBC in LMICs

\begin{tabular}{|c|c|c|c|}
\hline References & Variables of interest & Population & Design \\
\hline Cho et al., 2011 (Korea) $^{42}$ & $\begin{array}{l}\text { Communication needs with } \\
\text { physicians on the internet }\end{array}$ & $\begin{array}{l}1355 \text { women, aged } 22-65 \text { years, } \\
\text { mean } 38 \text { years }\end{array}$ & $\begin{array}{l}\text { Qualitative content analytic } \\
\text { approach } \\
\text { Instruments: Online Q and A } \\
\text { board }\end{array}$ \\
\hline $\begin{array}{l}\text { Edib et al., } 2016 \\
\text { (Malaysia) }^{33}\end{array}$ & $\begin{array}{l}\text { Prevalence of unmet supportive } \\
\text { care needs and QOL }\end{array}$ & $\begin{array}{l}133 \text { women, } 16 \text { YWBC aged < } \\
40 \text { years }(14 \%)\end{array}$ & $\begin{array}{l}\text { Cross-sectional } \\
\text { instruments: Supportive Care } \\
\text { Needs Survey-SF34; EORTC } \\
\text { QLQ-C30 }\end{array}$ \\
\hline $\begin{array}{l}\text { Barboza and Forero, } 2011 \\
(\text { Colombia) })^{54}\end{array}$ & $\begin{array}{l}\text { Religiosity/spirituality related } \\
\text { to depression and anxiety }\end{array}$ & $\begin{array}{l}61 \text { women, } 19 \text { women aged } \\
30-39 \text { years }(31 \%)\end{array}$ & $\begin{array}{l}\text { Descriptive, cross-sectional } \\
\text { study } \\
\text { Instruments: HADS Hospital } \\
\text { Anxiety and Depression Scale }\end{array}$ \\
\hline $\begin{array}{l}\text { Fong and Cheah, } 2016 \\
\text { (Malaysia) }^{34}\end{array}$ & $\begin{array}{l}\text { Prevalence of unmet needs and } \\
\text { associated factors }\end{array}$ & $\begin{array}{l}101 \text { women, mean } 57.9 \text { years, } \\
57 \text { women }<60 \text { years }(56 \%)\end{array}$ & $\begin{array}{l}\text { Cross-sectional study } \\
\text { Instruments: Supportive Care } \\
\text { Needs Survey-SF34 }\end{array}$ \\
\hline $\begin{array}{l}\text { Garduño et al., } 2010 \\
(\text { Mexico })^{27}\end{array}$ & $\begin{array}{l}\text { Effects of a cognitive-behavioral } \\
\text { intervention on QoL }\end{array}$ & 60 women, aged $31-67$ years & $\begin{array}{l}\text { Prospective study (pre-post) } \\
\text { Instruments: InCaViSa QoL } \\
\text { assessment with the inventory } \\
\text { of QoL and health }\end{array}$ \\
\hline $\begin{array}{l}\text { Iskandarsyah et al., } 2013 \\
\text { (Indonesia) }^{44}\end{array}$ & $\begin{array}{l}\text { Level of satisfaction regarding } \\
\text { the received information } \\
\text { addressing illness and } \\
\text { treatment, associations with } \\
\text { patients' illness perceptions, } \\
\text { and QoL }\end{array}$ & $\begin{array}{l}70 \text { women aged } 28-66 \text { years, } \\
\text { mean } 45.6 \text { years }\end{array}$ & $\begin{array}{l}\text { Correlational-descriptive study } \\
\text { instruments: Demographic } \\
\text { form, satisfaction with cancer } \\
\text { information profile, brief illness } \\
\text { perception questionnaire, and } \\
\text { the World Health Organization } \\
\text { QoL-BREF }\end{array}$ \\
\hline $\begin{array}{l}\text { Karaöz et al., } 2010 \\
\text { (Turkey) }\end{array}$ & $\begin{array}{l}\text { Needed and received } \\
\text { information regarding } \\
\text { contraception, early } \\
\text { menopause, infertility, fertility } \\
\text { preservation, and sexuality }\end{array}$ & 20 women, mean 40 years & $\begin{array}{l}\text { Qualitative exploratory } \\
\text { methodology }\end{array}$ \\
\hline $\begin{array}{l}\text { Ornelas-Mejorada et al., } \\
2011 \text { (Mexico) }^{31}\end{array}$ & $\begin{array}{l}\text { Prevalence of anxiety and } \\
\text { depression among women with } \\
\text { BC from radiotherapy }\end{array}$ & $\begin{array}{l}203 \text { women, women aged } 15-44 \\
\text { years }(23 \%)\end{array}$ & $\begin{array}{l}\text { Structured interviews } \\
\text { Instruments: HADS }\end{array}$ \\
\hline $\begin{array}{l}\text { Salas and Grisales, } 2010 \\
{\text { (Colombia })^{50}}^{\text {Colo }}\end{array}$ & $\begin{array}{l}\text { QoL in women diagnosed with } \\
\text { BC undergoing treatment }\end{array}$ & $\begin{array}{l}220 \text { women, aged } 28-80 \text { years, } \\
\text { median } 53.5 \text { years }\end{array}$ & $\begin{array}{l}\text { Cross-sectional study } \\
\text { Instruments: WHOQOL BREF } \\
\text { QoL }\end{array}$ \\
\hline $\begin{array}{l}\text { Sat-Muñoz et al., } 2011 \\
(\text { Mexico })^{49}\end{array}$ & $\begin{array}{l}\text { Socioeconomic factors, } \\
\text { comorbidities, and process of } \\
\text { care associated with QoL }\end{array}$ & 314 women, mean 52.2 years & $\begin{array}{l}\text { Cross-sectional study } \\
\text { Instruments: EORTC QLQ-C } 30 \text {, } \\
\text { IN-PATSAT32 }\end{array}$ \\
\hline
\end{tabular}


Table 1. Variables of interest, population, and design of studies addressing special needs of YWBC in LMICs (Continued)

\begin{tabular}{|c|c|c|c|}
\hline References & Variables of interest & Population & Design \\
\hline $\begin{array}{l}\text { Hoppenstedt, } 2005 \\
\text { (Mexico) })^{26}\end{array}$ & $\begin{array}{l}\text { Processes of change in self- } \\
\text { concept, emotions, and sense } \\
\text { of life in women with BC }\end{array}$ & 12 women, 10 aged $38-48$ years & $\begin{array}{l}\text { Qualitative study with } \\
\text { phenomenological analysis }\end{array}$ \\
\hline $\begin{array}{l}\text { Recalde and Samudio, } 2012 \\
(\text { Paraguay) })^{25}\end{array}$ & QoL in women with BC & $\begin{array}{l}125 \text { women aged } 25-90 \text { years, } \\
\text { mean } 55 \text { years }\end{array}$ & $\begin{array}{l}\text { Descriptive, cross-sectional } \\
\text { study } \\
\text { instruments: EORTC QLQ-C30, } \\
\text { EORTC QLQ-BR23 }\end{array}$ \\
\hline $\begin{array}{l}\text { Roquebert et al., } 2012 \\
(\text { Panama })^{48}\end{array}$ & $\begin{array}{l}\text { Barriers and opportunities in the } \\
\text { access and continuum of care }\end{array}$ & $\begin{array}{l}21 \text { women in focus groups and } \\
14 \text { were interviewed, overall } 7 \\
\text { patients aged }<50 \text { years }\end{array}$ & $\begin{array}{l}\text { Qualitative study } \\
\text { methodology: In-depth } \\
\text { individual interviews and focus } \\
\text { groups }\end{array}$ \\
\hline $\begin{array}{l}\text { Villarreal-Garza et al., } 2016 \\
\text { (Mexico) })^{40}\end{array}$ & $\begin{array}{l}\text { Describe the specific needs } \\
\text { among young } B C \text { patients in } \\
\text { Mexico through focus groups }\end{array}$ & $29 \mathrm{YW}$, aged $18-40$ years & $\begin{array}{l}\text { Cross-sectional, descriptive, } \\
\text { qualitative } \\
\text { instruments: Focus groups } \\
\text { through semi-structured } \\
\text { interviews }\end{array}$ \\
\hline $\begin{array}{l}\text { Villarreal-Garza et al., } 2016 \\
\text { (Mexico) }{ }^{45}\end{array}$ & $\begin{array}{l}\text { Understand the demographic } \\
\text { factors affecting the } \\
\text { information-seeking practices } \\
\text { of BC survivors in Mexico }\end{array}$ & $\begin{array}{l}310 \text { women, aged } 19-87 \text { years, } \\
113 \mathrm{YW} \text { aged } 18-40 \text { years } \\
(27 \%)\end{array}$ & $\begin{array}{l}\text { Cross-sectional, descriptive } \\
\text { Instruments: } 10 \text {-item self- } \\
\text { administered survey }\end{array}$ \\
\hline $\begin{array}{l}\text { Villarreal-Garza et al., } 2017 \\
(\text { Mexico) })^{36}\end{array}$ & $\begin{array}{l}\text { Evaluate the concerns of YW } \\
\text { with } B C \text { toward the risk of } \\
\text { infertility in two referral centers } \\
\text { in Mexico with access to public } \\
\text { health services }\end{array}$ & $134 \mathrm{YW}$, aged $\leq 40$ years & $\begin{array}{l}\text { Cross-sectional, descriptive } \\
\text { Instruments: } 25 \text {-item } \\
\text { in-person paper survey }\end{array}$ \\
\hline
\end{tabular}

QoL: quality of life; YW: young women; BC: breast cancer, LMICs: low- and middle- income countries; YWBC: young women breast cancer

Edib et al. studied Malayan women (38.5\% under 50 years of age) who had been diagnosed with $\mathrm{BC}$ at least 2 years before the study. In addition to presenting a high prevalence of unmet physical needs, these women reported, "feeling unwell a lot of the time" (51.8\%), "lack of energy and tiredness" (57.3\%), and pain $(55.6 \%)^{33}$. Likewise, during a study on the Malayan population, Fong and Cheah found a high prevalence of unmet physical needs among BC patients (median of 8.2 years of follow-up). They found that, on average, those under 60 years had higher levels of unmet physical (e.g., pain, lack of energy, work around the home, feeling unwell, and not being able to do the things they used to do) and sexual needs in comparison to older patients. Interestingly, they also found that patients with higher scholarship and $\leq 5$ year-survival reported greater physical needs ${ }^{34}$. A study of the needs of Turkish women with $B C$, including mainly women aged $<50$ years, found that the majority of those who had undergone adjuvant chemotherapy reported gradually losing their capacity to resume their normal daily activities due to fatigue ${ }^{35}$.

Villarreal-Garza et al. conducted the first-ever study aimed to identify fertility concerns among Mexican YWBC. The authors found that only $31 \%$ of patients recalled having received information regarding infertility risk from their physicians despite that $44 \%$ of women expressed some level of concern about infertility secondary to systemic treatment. They also found that the only factor significantly correlating with fertility concern in their sample was the previous desire to have children ${ }^{36}$.

In short, the main physical needs of YWBC indicate that they arise as side effects of oncologic treatment and are primarily associated to the time of exposure. The most common physical needs expressed by YWBC concern fertility and sexuality, whereas fatigue is the symptom more frequently reported by women with $\mathrm{BC}$ in general.

\section{Psychological needs}

Women diagnosed with BC undergo profound emotional and psychological distress, regardless of their age. The first impact is occurring at the moment they are informed about their diagnosis, at which time the majority of patients express being devastated. However, their suffering persists in the form of fear, anxiety, depression and feeling of mutilation related to surgery, chemotherapy, and radiotherapy ${ }^{26,31,37}$. Reviewed studies demonstrate that, when they find 

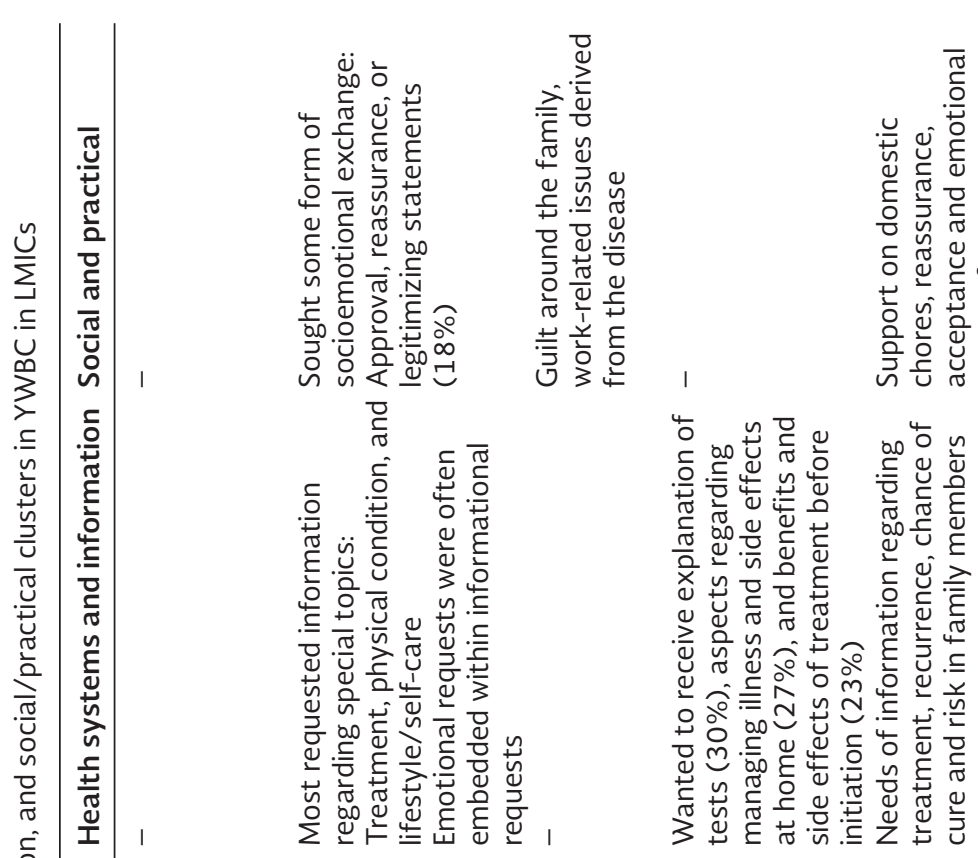

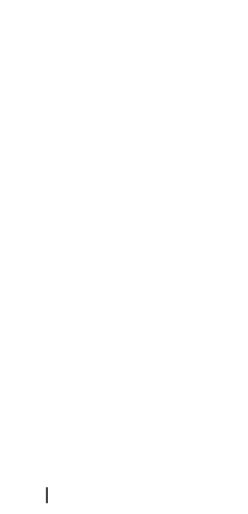

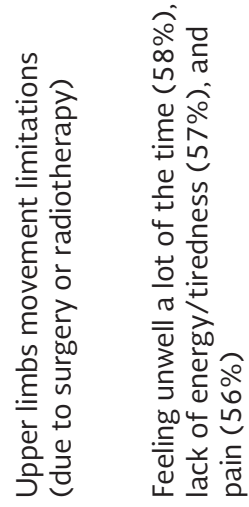

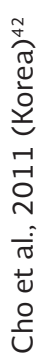

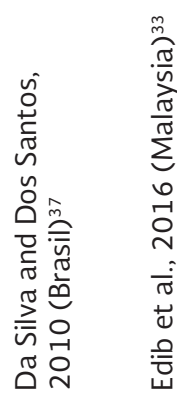
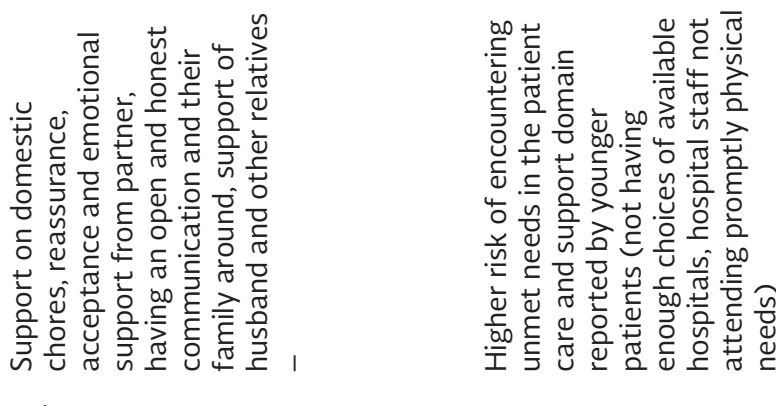

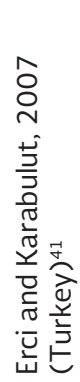

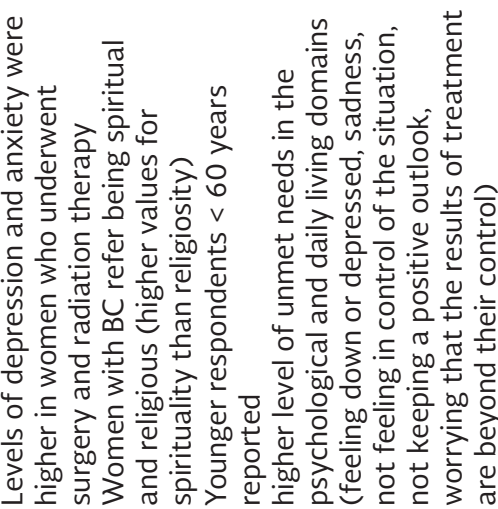
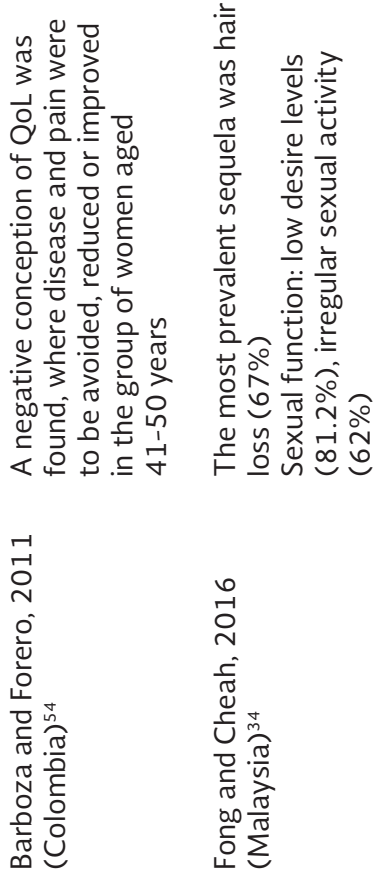


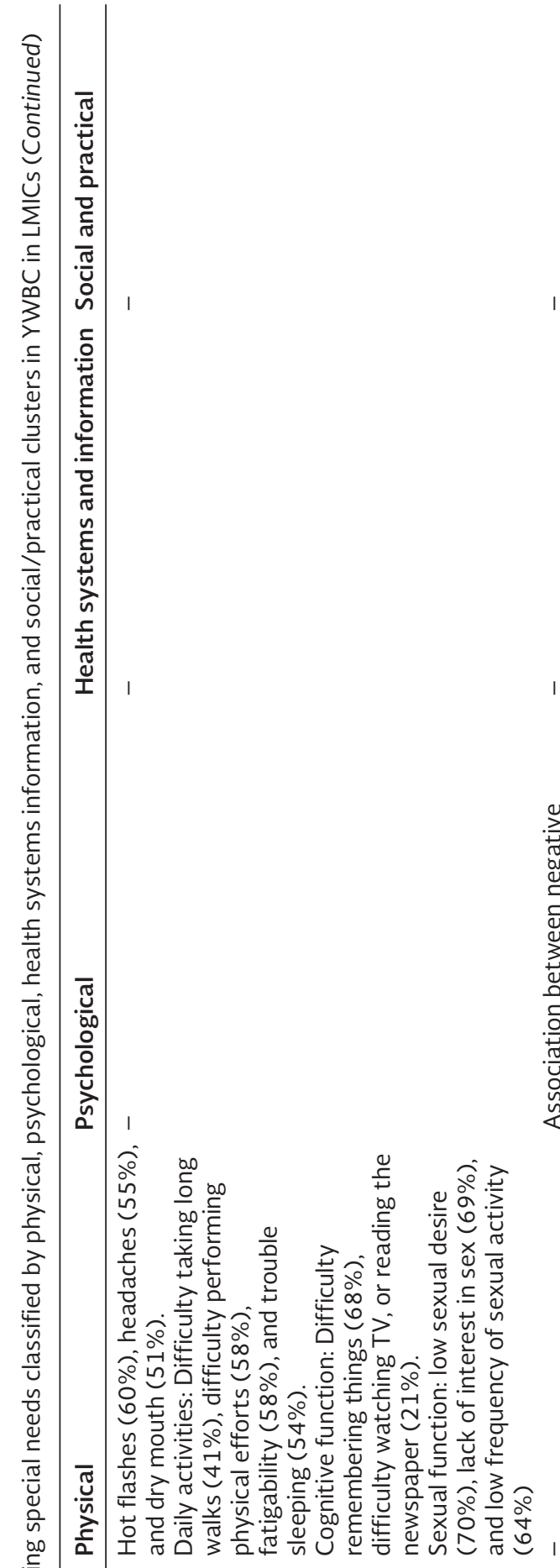

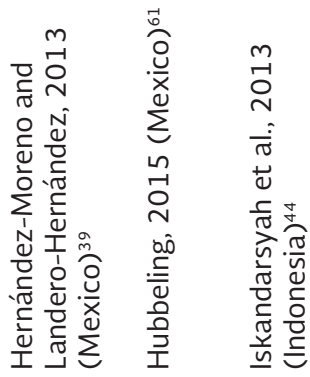

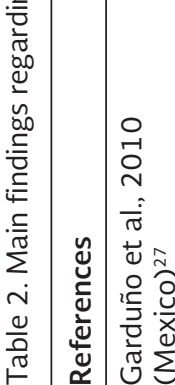

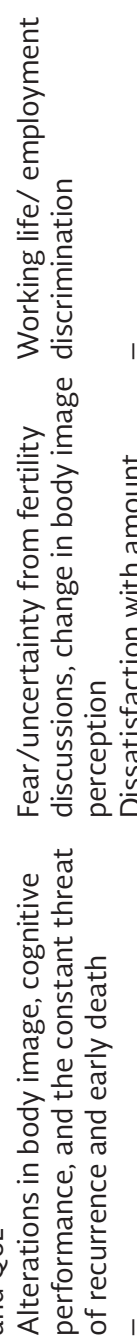

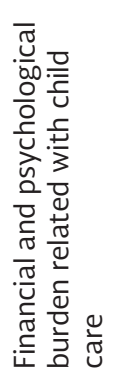
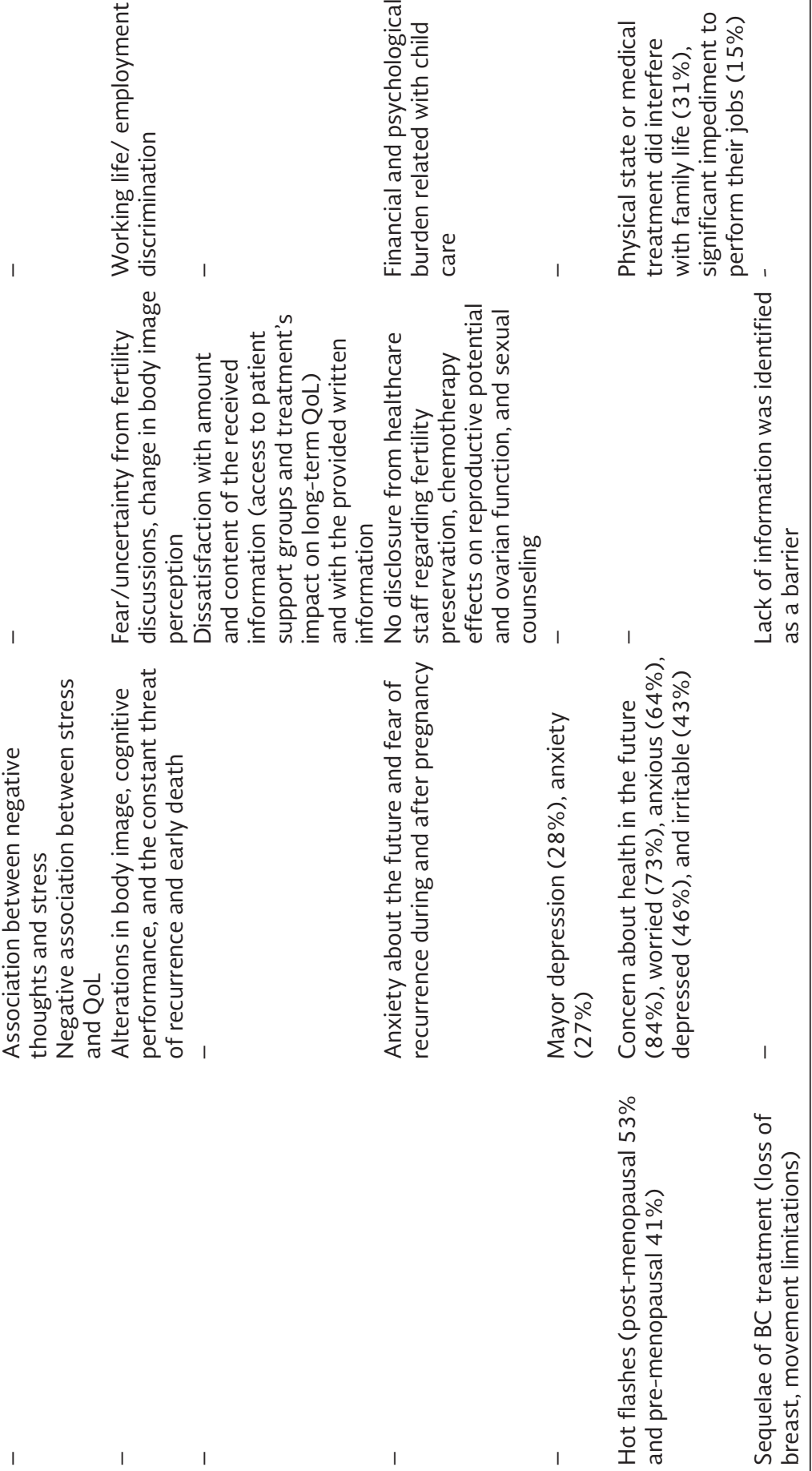
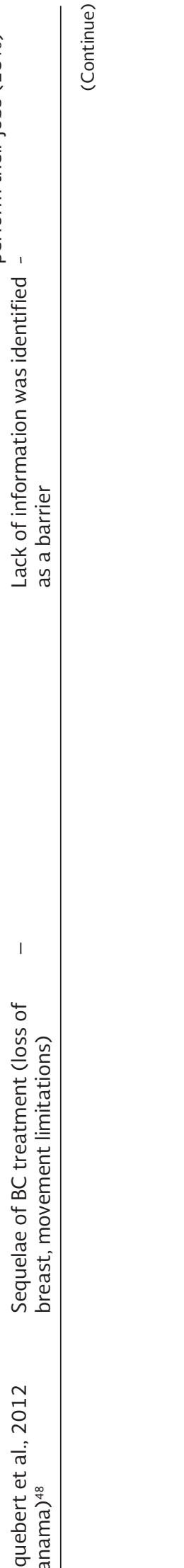

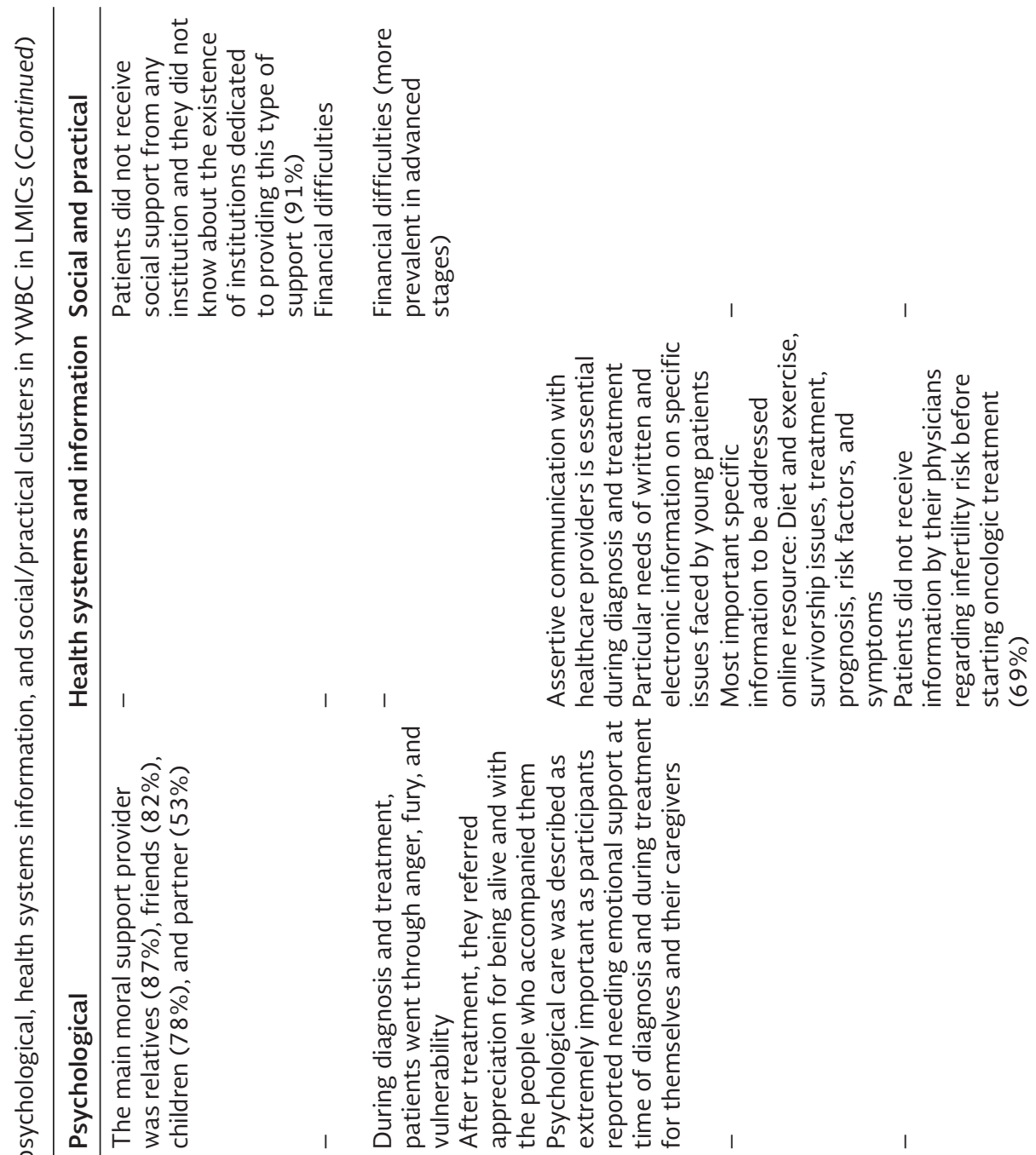

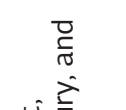

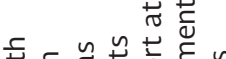

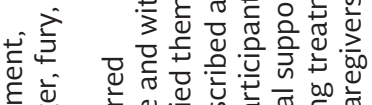

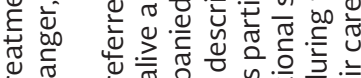

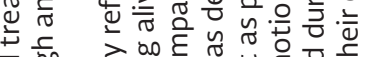

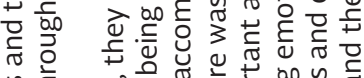

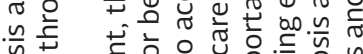

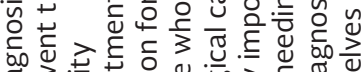

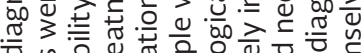

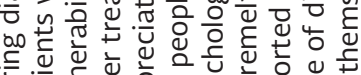

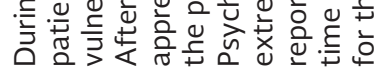

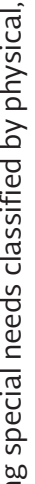

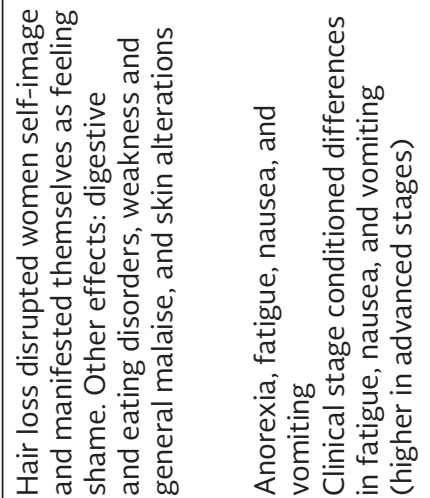

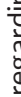

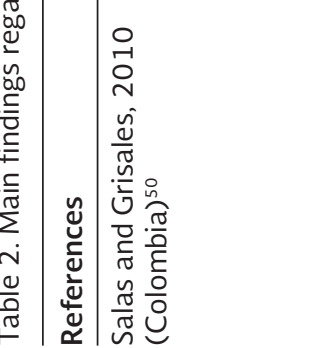

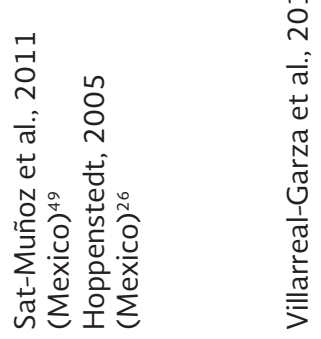

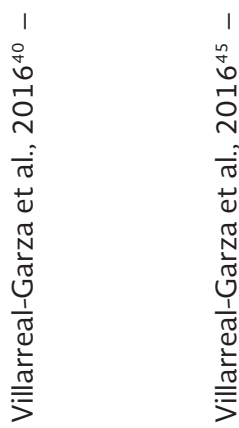

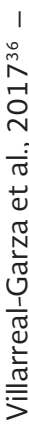

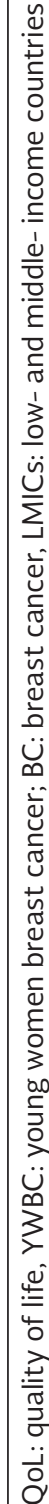

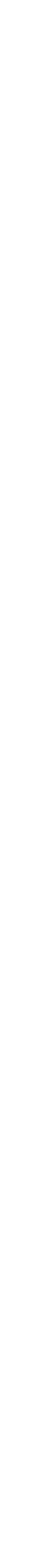


themselves unable to perform their normal activities at home and at the workplace, women experience distress, anxiety, and depression. The symptoms expressed most frequently are concern, nervousness, and irritability $24,25,29,38,39$. Various studies on the quality of life of BC patients report that women need understanding, affection, a quiet environment, time with their loved ones, and a strong family unit to face better the process of their illness and treatment. Studies also show that acceptance, a positive reinterpretation of the situation and use of social support, are the best strategies to cope with cancer in terms of health-related quality of life ${ }^{32}$. Finally, it has been observed that women with breast reconstruction obtained higher scores in the quality of life emotional component ${ }^{38}$.

Villarreal et al. studied a group of 29 young Mexican women aged 18-40 years, being to date the only study specifically addressing YWBC needs in Latin America. The authors described that psychological care was extremely important for this subgroup of patients, since participants reported needing emotional support at the time of diagnosis and during treatment for themselves and their caregivers ${ }^{40}$.

Turkish patients aged 20-45 years and who had recently undergone a mastectomy reported having unmet needs for support in managing changes in their perceived femininity and body image. Specifically, they referred a strong need to adjust to their changed appearance and to have this accepted by their husband/ partners ${ }^{41}$. Another Turkish group with an average age of 40 years (standard deviation $[S D]=5.2$ ), who had been diagnosed with early stage $\mathrm{BC}$ and had received various treatments, when they were asked about pregnancy, reported worry about the financial and psychological burden that came with an infant, and feeling anxious about the future and fearful that the disease could recur during and after pregnancy. In a Korean study, Cho et al. indicated that women with an average age of 38.4 years $(S D=9.6$ ), who had been diagnosed with $\mathrm{BC}$, manifested emotional requests often embedded within informational needs; $63 \%$ expressed both, concern and worry, and $75 \%$ of the requests included at least one emotional expression. The patients desired informational and psychological support, and expressed concern and restlessness (52.7\%) on this subject ${ }^{42}$.

Likewise, in Malayan BC patients, including YW, it has been described that psychological needs were the most frequently unmet. Among the unmet supportive care needs, the most prevalent were uncertainty over the future $(78.6 \%)$, fear about the cancer spreading (76.1\%), feelings of sadness ( $69.2 \%)$, and concerns about death and dying $(68.4 \%)^{33,34,41}$.

While no additional results were found specifically on YWBC, other studies that focus on this age group consistently address the psychological and psychosocial distress experienced by young patients. As it can be expected, one of the most intense psychological demands among young patients, who would otherwise be healthy, relates to the constant threat of recurrence and death ${ }^{2,12}$.

\section{Informational needs and the health system}

In their study of young Turkish women, Erci and Karabulut reported that their sample patients showed high levels of informational needs regarding BC diagnosis and treatment. They were particularly interested in signs of recurrence, opportunities for healing, and their family's vulnerability to cancer ${ }^{41}$.

In another Turkish study, this one on pre-menopausal patients with BC, Karaöz et al. found that none of the women had been offered counseling or had received information on contraception, early menopause, infertility, fertility preservation, and sexuality, despite their willingness to receive information. However, they reported being conscious of their need for contraception and attempted to obtain related information from other sources ${ }^{43}$.

In Indonesia, Iskandarsyah et al. assessed both, the extent to which patients were satisfied from the information they received and the association between satisfaction, on the one hand, and perception of the disease and quality of life on the other ${ }^{44}$. This study comprised 77 patients with a mean age of 45.6 years $(S D=7.88)$, $50 \%$ of whom were at an advanced stage at diagnosis and had most undergone surgery and chemotherapy. The authors found that many of the women were dissatisfied with the information they had received. For instance, regarding the amount and content of the information, they reported not having received what they needed to access a support group, to apply for financial aid and to understand how treatment could affect their ability to work. Most of the patients were also dissatisfied with the amount of written information provided. Those who reported being satisfied with the promptness 
of delivery and the types of information were characterized by having stronger beliefs in personal control, lesser concerns about their health condition, better understanding of their disease, and a positive perception of their psychological and general health.

The Malayan survivors, particularly those who were under 60 and had higher education levels as well as fewer years of survival, reported that information was the most needed item. They also indicated that the majority of their unmet needs fell within this category, namely, "having one member of the hospital staff with whom you can talk about all aspects of your condition, treatment, and follow-up" (34.7\%), "receiving explanations about the tests for which you would like to get more information" (29.7\%), and "having access to professional counseling if you or your family and friends need it" $(27.7 \%)^{34}$.

In exploring the demographic factors associated with the demand for information by young patients in Mexico, a qualitative study searching patients' needs through focus groups found that YW request written and electronic information about particular issues, such as fertility preservation, genetic counseling, and handling side effects $^{40}$. In addition, another study addressing YWBC in Mexico described that this population was more interested in learning about the adverse effects of treatment, but there was no difference between YWBC and their older counterparts regarding other aspects of perceived information needs. They also considered that receiving information through the internet was useful. The most important specific information survivors would have liked to see addressed in an online resource was diet and exercise, followed by issues related to survivorship, treatment, prognosis, risk factors, and symptoms ${ }^{45}$.

The informational needs of YWBC are related, in a large proportion, to their late stages at diagnosis. This clearly calls for targeted information strategies designed to raise awareness of the importance of timely diagnosis and treatment, and to modify the cultural habits and religious beliefs that might be hindering access of YW to healthcare services ${ }^{46}$. Healthcare interventions are also required to improve the quality of life, and written resources and web-based decision aids should be developed and routinely provided in young patients' native language $e^{2,12,47}$.

As for the needs regarding the healthcare system, young Panamanian women with BC experienced cost-related barriers and difficulties in obtaining medical appointments for their clinical assessment, obstructing the path to a timely health-service provision ${ }^{48}$.

To sum up, informational needs are described as the most frequent and important in this type of patients with BC. However, the need for specific information is different depending on clinical stages and treatment trajectory.

\section{Social needs}

The impact of $B C$ on intimate relationships is one of the most prevalent challenges women face while they adapt to their new body image after mastectomy ${ }^{24}$. Studies also associate the following social factors with diminished quality of life (physical and psychological) in BC-diagnosed women: Those who live in disadvantaged socioeconomic contexts, have low scholarship and are unpaired, experience acute levels of fatigue, pain, anxiety, and depression ${ }^{49}$. On the other hand, Salas and Grisales suggested that moral support from relatives and friends is fundamental to achieve a favorable quality of life perception ${ }^{50}$.

Erci and Karabulut found significant differences in perceived quality of life in Turkish women between the age groups 20-45 years versus $>54$ years, regarding a greater need of support from family and friends ${ }^{41}$. Similarly, Cho et al. explored the questions posed mainly by young patients to the physicians and observed a greater need for socioemotional support coupled with informational requests ${ }^{42}$.

As YW increasingly play a role for the household provision, workplace concerns are particularly relevant for these patients, as cancer diagnosis and treatment may affect their careers. In a Cuban study, IzquierdoGonzález et al. reported that as a consequence of BC diagnosis, some women changed their jobs to reduce their physical activity, and none encountered reinsertion difficulties subsequent to treatment ${ }^{24}$.

It is noteworthy that LMICs provide little or no available information on work-related issues (e.g., resuming work and discrimination/stigma) compared to HICs, where these issues are described in greater detail. The literature on HICs indicates that some women experience economic problems as a result of having to leave their work; BC can have a negative impact on women's decision to work; women with $B C$ are less likely to find employment than women who have not been ill; and 
survivors experience employment discrimination ${ }^{51-53}$. This topic offers an opportunity for further research in LMICs contexts.

\section{Spiritual needs}

Many of the women interviewed had existential (religious or spiritual) beliefs that favorably supported their perception of disease and gave them strength to cope with their condition ${ }^{50}$. At the time of diagnosis, the first thoughts of these women were that things happened by chance, destiny, or luck. Subsequently, when they reached the treatment, follow-up, and control stages (once they were tumor-free), they assured their "faith in God" had allowed them to get that far ${ }^{54}$. A diagnosis of cancer has been observed to arouse guilt and fear in these women, which they elaborate as a sign that one of the reasons for their diagnosis is punishment from God.

In a Mexican study, Gallegos-Alvarado et al. found that faith and spiritual beliefs offered women with BC a "reason to live," "gave meaning" to their lives, and enabled them to find well-being and inner peace. On this basis, women in their study succeeded in adapting to their condition and enduring treatments required for their health care ${ }^{55}$. A study on the spiritual perspective of Colombian women with BC indicated that spirituality allowed women to "find forgiveness" (patients often have guilt feelings in relation to their illness) and to "make existential reflections" as they attempted to find life's meaning and to discover what disease and pain represented for their transcendence and inner happiness. These reflections were pursued through meditation and private prayer ${ }^{56}$. In Chile, Choumanova et al. analyzed how religion and spirituality helped women with $B C$ deal with their illness, how the disease changed the role of religion and spirituality in their lives and how faith helped them recover ${ }^{57}$. According to their findings, these women depended on God to guide them through their illness and received extensive social support from the members of their faith communities. Many declared that BC had increased the presence of religion and spirituality in their lives by deepening their faith in God. Almost all women endorsed the idea that faith could help patients to recover from cancer.

A study in Iran explored how women faced a cancer diagnosis and observed a combination of attitudes: Some women exhibited positive thinking in the form of hope and intentional oblivion; others held negative thoughts resulting in hopelessness and fear. The authors concluded that faith played a major role in coping with disease and considered that their findings served to design new healthcare approaches in nursing ${ }^{58}$.

In short, spirituality occupies a fundamental place on the lives of these women as they attempt to resume their former lifestyle and daily routines, and strive to make sense of this experience. There are no studies from the region that explore the needs on spirituality and religion among $\mathrm{YW}$.

\section{Practical needs}

The most important finding reported in the literature referred to the dramatic changes in lifestyle that women, and those around them, must endure. As mentioned previously, women with BC are often hindered from performing their normal activities, particularly those related to their family dynamics. As a consequence, roles within the household must be redistributed (e.g., childcare for small and adolescent children and caregiving for family members who are ill or disabled). BC survivors, therefore, lose their autonomy and become dependent on the decisions of others.

Erci and Karabulut observed that patients perceived a need for physical and practical support to perform a number of activities after leaving the hospital and during treatment ${ }^{41}$. Furthermore, according to Karaöz et al., women worried that having a child would pose an unsustainable financial and psychological burden should they choose to become pregnant after BC treatment ${ }^{43}$. As YW might face employment difficulties during diagnosis, treatment, and survivorship, the deriving economic problems that affect their family finances could force them and their families to engage in new activities ${ }^{29,49}$.

To conclude the former, practical needs in YWBC focus mainly on lifestyle disturbances and their consequences on the household, financial instability as well as unemployment issues.

\section{DISCUSSION}

In summary, patients with $B C$ described throughout the literature exhibited diverse and frequent needs in all the analytical categories ${ }^{59}$. The most common unmet needs in the literature were related to information (e.g., demands from the healthcare system) and psychological support, followed by practical and physical needs. Social needs were the ones least reported and spiritual needs the ones least studied. 
Informational needs were related mainly to treatment side effects (i.e. signs and symptoms and management recommendations), the possibility of recurrence, susceptibility of family members to cancer, and adaptation strategies subsequent to treatment.

Psychological needs referred to the support required in handling the emotional impact produced by both, treatment side effects and threat of recurrence and death (fear and uncertainty).

Physical needs were related mostly to assistance after surgery and during chemotherapy, as well as survivorship-related issues, mainly secondary to oncologic treatment such as induced ovarian failure, premature menopause, sexual dysfunction, and cognition impairment.

As YWBC perceived a less favorable social environment, their social needs involved greater support from family and friends for coping with the associated changes that cancer treatment imposed on their social roles.

Furthermore, the socioeconomic and cultural contexts of $\mathrm{BC}$ patients clearly permeate their entire disease process, beginning with their condition before diagnosis, continuing with treatment and survivorship, and culminating with death, particularly in young patients.

To address the physical, psychological, and informational needs of these patients, healthcare systems in LMICs must elaborate and implement integral, multidisciplinary programs that respond opportunely to the problems arising from disease and to the side effects of oncologic treatments. It is particularly important to develop strategies that guarantee fertility preservation for those who require it; to target actions which ensure an improved and long-term quality of life for survivors through an adequate management of early menopause and sexual dysfunction; and to implement timely psychological interventions which prevent emotional symptoms that lead to depression. It is also essential for physicians, nurses, psychologists, and social workers to make efforts in sustaining interpersonal communication with patients, and to identify the most effective mechanisms, whether verbal or written, for meeting the information needs of women with BC and their families.

Specifically, regarding YWBC in LMICs, it is striking that the existing information on the subject is scarce, particularly in Latin America. Numerous opportunities, therefore, exist for promoting research, training of health personnel, and establishing health policies in support of these women to, in the end, improve health outcomes.

The key limitation of our literature review encompasses the difficulties encountered in identifying studies on women, especially YWBC in LMICs. Since it was virtually impossible to find references using the key words which we initially established, we broadened the terms of our search to encompass studies on the psychosocial effects of diagnosis and treatment in women with $\mathrm{BC}$ in general, and included documents addressing the needs of women under 50 . While other, unidentified, literature may have been omitted, our study provides a unique collection of research studies of this type.

\section{REFERENCES}

1. Porter P. "Westernizing" women's risks? Breast cancer in lower-income countries. N Engl J Med. 2008;358:213-6.

2. Villarreal-Garza C, Aguila C, Magallanes-Hoyos MC, et al. Breast cancer in youzng women in Latin America : An unmet, growing burden. Oncologist. 2013;18:1298-306.

3. Knaul F, Bustreo F, Ha E, Langer A. Breast cancer: Why link early detection to reproductive health interventions in developing countries? Salud Publica Mex. 2009;51 Suppl 2:s220-7.

4. Crippa CG, Hallal AL, Dellagiustina AR, Traebert ÉE, Gondin G, Pereira C. Perfil clínico e epidemiológico do câncer de mama em mulheres jovens. Arq Catarinenses Med. 2003;32:50-8.

5. Farouk O, Ebrahim MA, Senbel A, et al. Breast cancer characteristics in very young Egyptian women equal or less than 35 years. Breast Cancer Targets Ther. 2016;8:53-8.

6. Ganz PA, Yip CH, Gralow JR, et al. Supportive care after curative treatment for breast cancer (survivorship care): Resource allocations in low-and middle-income countries. A Breast Health Global Initiative 2013 consensus statement. Breast. 2013;22: 606-15.

7. Knaul FM, Gralow JR, Atun R, et al. Closing the cancer divide: Overview and summary. In: Closing the Cancer Divide: An Equity Imperative. Cambridge, MA: Harvard Global Equity Initiative; 2012. p. 3-27.

8. Partridge AH, Ruddy KJ, Kennedy J, Winer EP. Model program to improve care for a unique cancer population: young women with breast cancer. J Oncol Pract 2012;8:e105-10.

9. Narod SA. Breast cancer in young women. Nat Rev Clin Oncol. 2012;9:460-70.

10. Recio-Saucedo A, Gerty S, Foster C, Eccles D, Cutress RI. Information requirements of young women with breast cancer treated with mastectomy or breast conserving surgery: A systematic review. Breast. 2016;25:1-13.

11. Avis NE, Crawford S, Manuel J. Psychosocial problems among younger women with breast cancer. Psychooncology. 2004;13: 295-308.

12. Gravena AA, Agnolo CM, Lopes TC, et al. Breast cancer in young Brazilian women: Challenge for the oncology care. Epidemiol Res Int. 2014;2014:1-6.

13. Harford JB. Breast-cancer early detection in low-income and middle-income countries: Do what you can versus one size fits all. Lancet Oncol. 2011;12:306-12.

14. Coleman MP, Quaresma M, Berrino F, et al. Cancer survival in five continents: A worldwide population-based study (CONCORD). Lancet Oncol. 2008;9:730-56.

15. Franco-Marina F, López-Carrillo L, Keating NL, Arreola-Ornelas H, Marie Knaul F. Breast cancer age at diagnosis patterns in four Latin American populations: A comparison with North American countries. Cancer Epidemiol. 2015;39:831-7. 
16. Othieno-Abinya NA, Nyabola LO, Abwao HO, Ndege $P$. Postsurgical management of patients with breast cancer at Kenyatta National Hospital. East Afr Med J. 2002;79:156-62.

17. Rodin D, Knaul FM, Lui TY, Gospodarowicz M. Radiotherapy for breast cancer: The predictable consequences of an unmet need. Breast. 2016;29:120-2.

18. Errico KM, Rowden D. Experiences of breast cancer survivor-advocates and advocates in countries with limited resources: A shared journey in breast cancer advocacy. Breast J. 2006;12 Suppl 1:S111-6.

19. Adams E, McCann L, Armes J, et al. The experiences, needs and concerns of younger women with breast cancer: A meta-ethnography. Psychooncology. 2011;20:851-61.

20. Peate M, Meiser B, Hickey M, Friedlander M. The fertility-related concerns, needs and preferences of younger women with breast cancer: A systematic review. Breast Cancer Res Treat. 2009:116:215-23.

21. Ferrell BR, Hassey Dow K. Quality of life among long-term cancer survivors. Oncology (Williston Park). 1997;11:565-8.

22. Mullan F. Seasons of survival: Reflections of a physician with cancer. N Engl J Med. 1985;313:270-3.

23. Villarreal-Garza C, Martinez-Cannon BA, Platas A, Ramos-Elias P. Specialized programs to support young women with breast cancer. Curr Opin Support Palliat Care. 2015;9:308-16.

24. Izquierdo-González M, González-Pérez U, Alerm-González A, Jáuregui-Haza U. Calidad de vida en un grupo de mujeres cubanas con cáncer de mama. Rev Haban Cienc Méd. 2008;7:1-11.

25. Recalde M, Samudio M. Calidad de vida en pacientes con cáncer de mama en tratamiento oncológico ambulatorio en el Instituto de Previsión Social en el año 2010. Quality of life in patients with breast cancer undergoing ambulatory oncologic treatment at the Social Security Institute. Mem Inst Investig Cienc Salud. 2012;10:13-29.

26. Hoppenstedt GE. Autoconcepto, Emociones y Sentido de Vida de Mujeres Con Cáncer de Mama. Tesis Completa. Tesis. Mexico: Universidad Iberoamericana; 2005.

27. Garduño C, Riveros A, Sánchez-Sosa JJ. Calidad de vida y cáncer de mama: Efectos de una intervención cognitivo-conductual. Rev Latinoam Med Conduct/Lat Am J Behav Med. 2010;1:69-80.

28. Avis NE, Crawford S, Manuel J. Quality of life among younger women with breast cancer. J Clin Oncol. 2005:23:3322-30.

29. Lafaurie VM, Choachí SJ, Gómez JÁ, et al. Mujeres con cáncer de seno: Experiencias y significados. Rev Colomb Enfermería. 2011;7:12-22

30. Gluhoski VL, Siegel K, Gorey E. Journal of psychosocial self-esteem and well-being among women with breast cancer and women in an age- matched comparison group. J Psychosoc Oncol. 2015;7332:37-41.

31. Ornelas-Mejorada RE, Tufiño MA, Sánchez-Sosa Jj. Ansiedad y depresión en mujeres con cáncer de mama en radioterapia: Prevalencia y factores asociados. Acta Investig Psicol. 2011:1:401-14

32. Reich M, Remor E. Eficacia de la terapia cognitivo conductual en mujeres con cáncer de mama. Psicooncologia. 2011:8:453-71.

33. Edib Z, Kumarasamy V, Binti Abdullah N, Rizal AM, Al-Dubai SA. Most prevalent unmet supportive care needs and quality of life of breast cancer patients in a tertiary hospital in Malaysia. Health Qual Life Outcomes. 2016;14:26

34. Fong EJ, Cheah WL. Unmet supportive care needs among breast cancer survivors of community-based support group in Kuching, Sarawak. Int J Breast Cancer. 2016;2016:7297813.

35. Can G, Durna Z, Aydiner A. Assessment of fatigue in and care needs of Turkish women with breast cancer. Cancer Nurs. 2004;27:153-61.

36. Villarreal-Garza C, Martinez-Cannon BA, Platas A, Mohar A, Partridge AH, Gil-Moran A, et al. Fertility concerns among breast cancer patients in Mexico. Breast. 2017;33:71-5.

37. Da Silva G, Dos Santos MA. Factores estresantes del post-tratamiento del cáncer de mama: Un enfoque cualitativo. Rev Latino Am Enferm. 2010;18:22.

38. Bajuk L, Reich M. Calidad de vida relacionada con la salud en mujeres uruguayas con cáncer de mama. Cien Psicol. 2011;5:19-30
39. Hernández-Moreno F, Landero-Hernández R. Aspectos psicosociales relacionados con la calidad de vida en mujeres con cáncer de mama. Summa Psicol Ust. 2014:11:99-104.

40. Villarreal-Garza C, LGH, MM, et al. A focus group study of unmet needs in Mexican young women with breast cancer. In: $3^{\text {rd }}$ ESO-ESMO Breast Cancer in Young Women International Conference (BCY3). Lugano, $\mathrm{CH} ; 2016$.

41. Erci B, Karabulut N. Appraising the self-assessed support needs of Turkish women with breast cancer. Eur J Cancer Care (Engl). 2007:16:137-43.

42. Cho J, Smith KC, Roter D, Guallar E, Noh DY, Ford DE. Needs of women with breast cancer as communicated to physicians on the Internet. Support Care Cancer. 2011;19:113-21.

43. Karaöz B, Aksu H, Küçük M. A qualitative study of the information needs of premenopausal women with breast cancer in terms of contraception, sexuality, early menopause, and fertility. Int J Gynaecol Obstet. 2010;109:118-20.

44. Iskandarsyah A, de Klerk C, Suardi DR, Soemitro MP, Sadarjoen SS, Passchier J. Satisfaction with information and its association with illness perception and quality of life in Indonesian breast cancer patients. Support Care Cancer. 2013;21:2999-3007.

45. Villarreal-Garza C, Platas A, Martinez-Cannon BA, et al. Information needs and internet use of breast cancer survivors in Mexico. Breast J. 2017;23(3):373-5.

46. Sighoko D, Kamaté B, Traore $C$, et al. Breast cancer in pre-menopausal women in West Africa: Analysis of temporal trends and evaluation of risk factors associated with reproductive life. Breast. 2013;22:828-35

47. Kruger WM, Apffelstaedt JP. Young breast cancer patients in the developing world: Incidence, choice of surgical treatment and genetic factors. S Afr Fam Pract. 2007;49:19-24.

48. Roquebert M, Palacios $G$, Ramos $Y$. Barreras y oportunidades en la atención de salud en mujeres con cáncer de mama de la ciudad de Panamá. Año 2012; 2012.

49. Sat-Muñoz D, Contreras-Hernández I, Balderas-Peña LM, et al. Calidad de vida en mujeres mexicanas con cáncer de mama en diferentes etapas clínicas y su asociación con características socio-demográficas, estados co-mórbidos y características del proceso de atención en el Instituto Mexicano del Seguro Social. Value Heal. 2011;14 5 Suppl: S133-6.

50. Salas C, Grisales H. Calidad de vida y factores asociados en mujeres con cáncer de mama en Antioquia, Colombia. Rev Panam Salud Pública. 2010;28:9-18.

51. Bradley CJ, Bednarek HL, Neumark D. Breast cancer and women's labor supply. Health Serv Res. 2002;37:1309-28.

52. Maunsell E, Drolet M, Brisson J, Brisson C, Mâsse B, Deschênes L. Work situation after breast cancer: Results from a population-based study. J Natl Cancer Inst. 2004;96:1813-22.

53. Bouknight RR, Bradley CJ, Luo Z. Correlates of return to work for breast cancer survivors. J Clin Oncol. 2006;24:345-53.

54. Barboza CF, Forero MJ. Anxiety and depression in breast cancer patients and its relation with their spirituality/religiosity. A preliminary data analysis. Rev Psicol. 2011:3:7-27.

55. Gallegos-Alvarado M, Hernández-Herrera DD, Eunice D. Bienestar espiritual en pacientes con cáncer de mama identificado a través de la relación enfermera-paciente. Rev Enferm Inst Mex Seguro Soc. 2008;16:99-104.

56. Galvis-López MA, Pérez-Giraldo B. Perspectiva espiritual de la mujer con cáncer. Aquichan. 2011;11:256-73.

57. Choumanova I, Wanat S, Barrett R, Koopman C. Religion and spirituality in coping with breast cancer: Perspectives of Chilean women. Breast J. 2006:12:349-52.

58. Taleghani F, Yekta ZP, Nasrabadi AN. Coping with breast cancer in newly diagnosed Iranian women. J Adv Nurs. 2006;54: 265-72.

59. Li WW, Lam WW, Au AH, et al. Interpreting differences in patterns of supportive care needs between patients with breast cancer and patients with colorectal cancer. Psychooncology. 2013:22:792-8.

60. Villarreal-Garza C, Platas A, Bargalló-Rocha JE, et al. Experiencia en el instituto nacional de cancerología. Rev Mex Mastol. $2015 ; 5: 12-7$ 